\title{
Indirect consequences of hypolimnetic hypoxia on zooplankton growth in a large eutrophic lake
}

\author{
Daisuke Goto ${ }^{1,8, *}$, Kara Lindelof ${ }^{2,3}$, David L. Fanslow ${ }^{4}$, Stuart A. Ludsin ${ }^{4,5}$, \\ Steven A. Pothoven ${ }^{4}$, James J. Roberts ${ }^{2,6}$, Henry A. Vanderploeg ${ }^{4}$, Alan E. Wilson ${ }^{2,7}$, \\ Tomas O. Höök ${ }^{1,2}$ \\ ${ }^{1}$ Department of Forestry and Natural Resources, Purdue University, West Lafayette, Indiana 47907, USA \\ ${ }^{2}$ Cooperative Institute for Limnology and Ecosystems Research, University of Michigan, Ann Arbor, Michigan 48108, USA \\ ${ }^{3}$ Department of Environmental Sciences, University of Toledo, Toledo, Ohio 43606, USA \\ ${ }^{4}$ Great Lakes Environmental Research Laboratory, National Oceanic and Atmospheric Administration, Ann Arbor, \\ Michigan 48108, USA \\ ${ }^{5}$ Aquatic Ecology Laboratory, Department of Evolution, Ecology and Organismal Biology, The Ohio State University, \\ Columbus, Ohio 43212, USA \\ ${ }^{6}$ Colorado State University, Department of Fish, Wildlife and Conservation Biology, Fort Collins, Colorado 80523, USA \\ ${ }^{7}$ Department of Fisheries and Allied Aquacultures, Auburn University, Auburn, Alabama 36849, USA \\ ${ }^{8}$ School of Biological Sciences, University of Nebraska Lincoln, Lincoln, Nebraska 68588, USA
}

\begin{abstract}
Diel vertical migration (DVM) of some zooplankters in eutrophic lakes is often compressed during peak hypoxia. To better understand the indirect consequences of seasonal hypolimnetic hypoxia, we integrated laboratory-based experimental and field-based observational approaches to quantify how compressed DVM can affect growth of a cladoceran, Daphnia mendotae, in central Lake Erie, North America. To evaluate hypoxia tolerance of $D$. mendotae, we conducted a survivorship experiment with varying dissolved oxygen concentrations, which demonstrated high sensitivity of $D$. mendotae to hypoxia $\left(\leq 2 \mathrm{mg} \mathrm{O}_{2} \mathrm{l}^{-1}\right)$, supporting the field observations of their behavioral avoidance of the hypoxic hypolimnion. To investigate the effect of temporary changes in habitat conditions associated with the compressed DVM, we quantified the growth of $D$. mendotae, using a 3 (food quantity) $\times 2$ (temperature) factorial design laboratory experiment. Neither food quantity nor temperature affected short-term growth in body length of $D$. mendotae. However, D. mendotae RNA content (an index of short-term condition) decreased under starvation, indicating an immediate response of short-term feeding on condition. We further evaluated the effect of hypoxia-induced upward shifts in vertical distribution by quantifying the RNA content of $D$. mendotae from central Lake Erie before and during peak hypoxia. Despite high temperature and food quantity in the upper water column, RNA content in field-collected D. mendotae remained low during peak hypoxia. Furthermore, D. mendotae collected during peak hypoxia consisted of only small-bodied $(<\sim 1.25 \mathrm{~mm})$ individuals, suggesting that behavioral avoidance of the hypoxic hypolimnion may also have indirect fitness costs.
\end{abstract}

KEY WORDS: Anoxia $\cdot$ RNA:DNA ratio $\cdot$ Food web $\cdot$ Great Lakes $\cdot$ Eutrophication $\cdot$ Zooplankton ecology

Resale or republication not permitted without written consent of the publisher

\section{INTRODUCTION}

Life history strategies of zooplankton reflect physiologically and behaviorally plastic responses to envi- ronmental heterogeneity (Lampert 2011). In turn, the vertical distribution of zooplankton is determined by active habitat selection based on environmental conditions and species-specific physiological and eco- 
logical preferences that optimize fitness (Wright \& Shapiro 1990, Lampert 2011). In particular, behavioral selection of suitable growth conditions and avoidance of potential mortality risks (e.g. predation, ultraviolet radiation) can drive zooplankton diel vertical migration (DVM) in aquatic ecosystems (Lampert 2011, Williamson et al. 2011).

In eutrophic lakes, dissolved oxygen (DO) concentrations of less than $2 \mathrm{mg} \mathrm{O}_{2} \mathrm{l}^{-1}$ (i.e. hypoxia) in the hypolimnion can disrupt normal DVM of zooplankton during summer (Hanazato et al. 1989, Wright \& Shapiro 1990, Lass et al. 2000). Thermal stratification of these lakes facilitates hypoxia development in the hypolimnion during summer as high rates of microbial decomposition and respiration deplete hypolimnetic oxygen (Yerubandi et al. 2008). While some zooplankton species (e.g. Daphnia pulicaria) can tolerate hypoxia to some extent (creating hypoxiamediated temporary predation refugia; Larsson \& Lampert 2011), seasonal hypoxia can make the hypolimnion uninhabitable for intolerant species (Wright \& Shapiro 1990, Vanderpleog et al. 2009a). As a result, hypoxia-intolerant zooplankton may experience direct hypoxia-induced mortality if they remain in the hypolimnion, or an alternative diel cycle of habitat conditions if they are forced to move to the upper water column (vertical habitat compression; Taylor \& Rand 2003, Pothoven et al. 2009, Vanderpleog et al. 2009a).

Vertically migrating zooplankton experience a variety of environmental gradients as they move through depth layers (Lampert 1989, Lampert et al. 2003). Herbivorous zooplankton such as Daphnia normally migrate downward into the dark hypolimnion during the day (i.e. light-dependent vertical migration), whereas these individuals will migrate upward into the epilimnion at night to seek habitat conditions that often favor enhanced growth (e.g. warm temperature and greater food availability) (Lampert 2011). Numerous studies have examined DVM of Daphnia spp. and their physiological and ecological responses to varying water temperatures and food (i.e. phytoplankton) concentrations encountered during these migrations (e.g. Orcutt \& Porter 1984, Stich \& Lampert 1984, McKee \& Ebert 1996). However, the relative importance of temperature and food to Daphnia growth appears to be highly variable, species-specific, and context-dependent (Stich \& Lampert 1984, Havel \& Lampert 2006).

In seasonally-stratified lakes, migrating Daphnia experience a steep temperature gradient from the epilimnion to the hypolimnion. While aggregations of phytoplankton often occur in the epilimnion during summer, high phytoplankton concentrations in the metalimnion or hypolimnion (deep chlorophyll maxima, DCM) are not uncommon (e.g. Williamson et al. 1996, Cole et al. 2002) and may decouple temperature and food concentration gradients (Williamson et al. 1996, Winder et al. 2003). With behavioral avoidance of the hypolimnion during peak hypoxia, hypoxia-intolerant Daphnia spp. may temporarily experience truncated diel cycles of temperature and food concentration gradients, which can affect growth and reproduction in eutrophic lakes (Larsson \& Lampert 2011).

We describe laboratory experiments and field observations that sought to elucidate how seasonal hypolimnetic hypoxia can affect the growth of the cladoceran Daphnia mendotae in a large seasonally stratified lake, central Lake Erie (USA and Canada; Fig. 1). Field surveys suggested that $D$. mendotae are highly intolerant of hypoxia; during the peak hypoxia season in summer, individuals virtually disappeared from the hypolimnion, where DO concentration was below $2 \mathrm{mg} \mathrm{O}_{2} \mathrm{l}^{-1}$ (Fig. 2c) (Vanderpleog et al. 2009a). To quantitatively evaluate DO tolerance of $D$. mendotae, we first conducted survivorship experiments with varying DO concentrations. While remaining in the upper water column during the day can affect predation risk, D. mendotae that avoid the hypolimnion also will experience an alternative diel cycle of habitat conditions. To investigate the indirect sublethal effect of seasonal hypoxia development (i.e. temporary changes in habitat conditions due to truncated DVM), we quantified the effect of differential food quantity on growth and RNA content (a biochemical indicator of condition) at temperatures typical of the hypolimnion and epilimnion in central Lake Erie. Finally, to explore how alternative habitat conditions (e.g. temperature and food concentration) resulting from truncated DVM affect realized growth potential, we examined a temporal change (from pre- to peak-hypoxia seasons) in RNA content in D. mendotae from central Lake Erie.

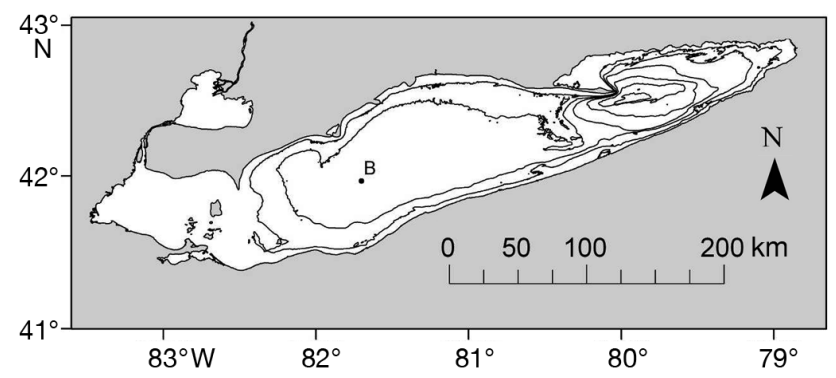

Fig. 1. Location of Study Site B (depth: $23.2 \mathrm{~m}$ ) in the central basin of Lake Erie, with bathymetry shown by $10 \mathrm{~m}$ contour lines 


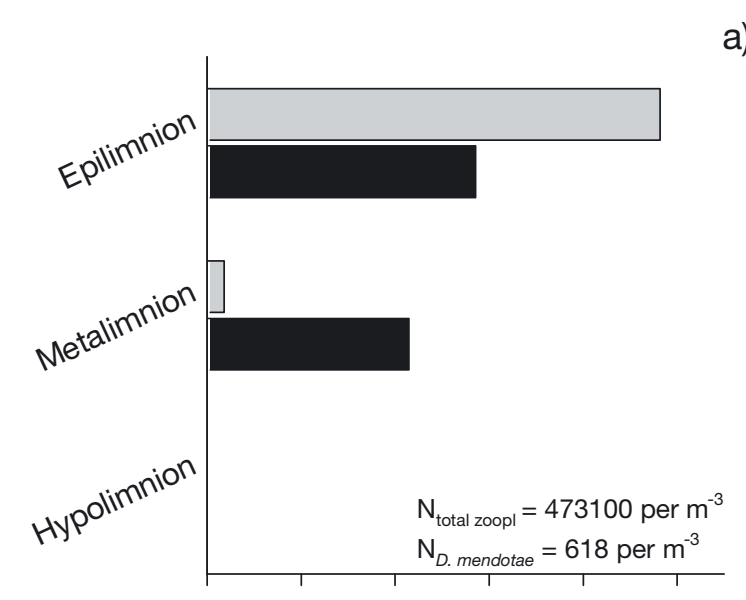

a) June

Temperature ( $\left.{ }^{\circ} \mathrm{C}\right)$; DO $\left(\mathrm{mg} \mathrm{l}^{-1}\right)$; $\mathrm{Chl} \mathrm{a}\left(\mu \mathrm{g} \mathrm{l}^{-1}\right)$
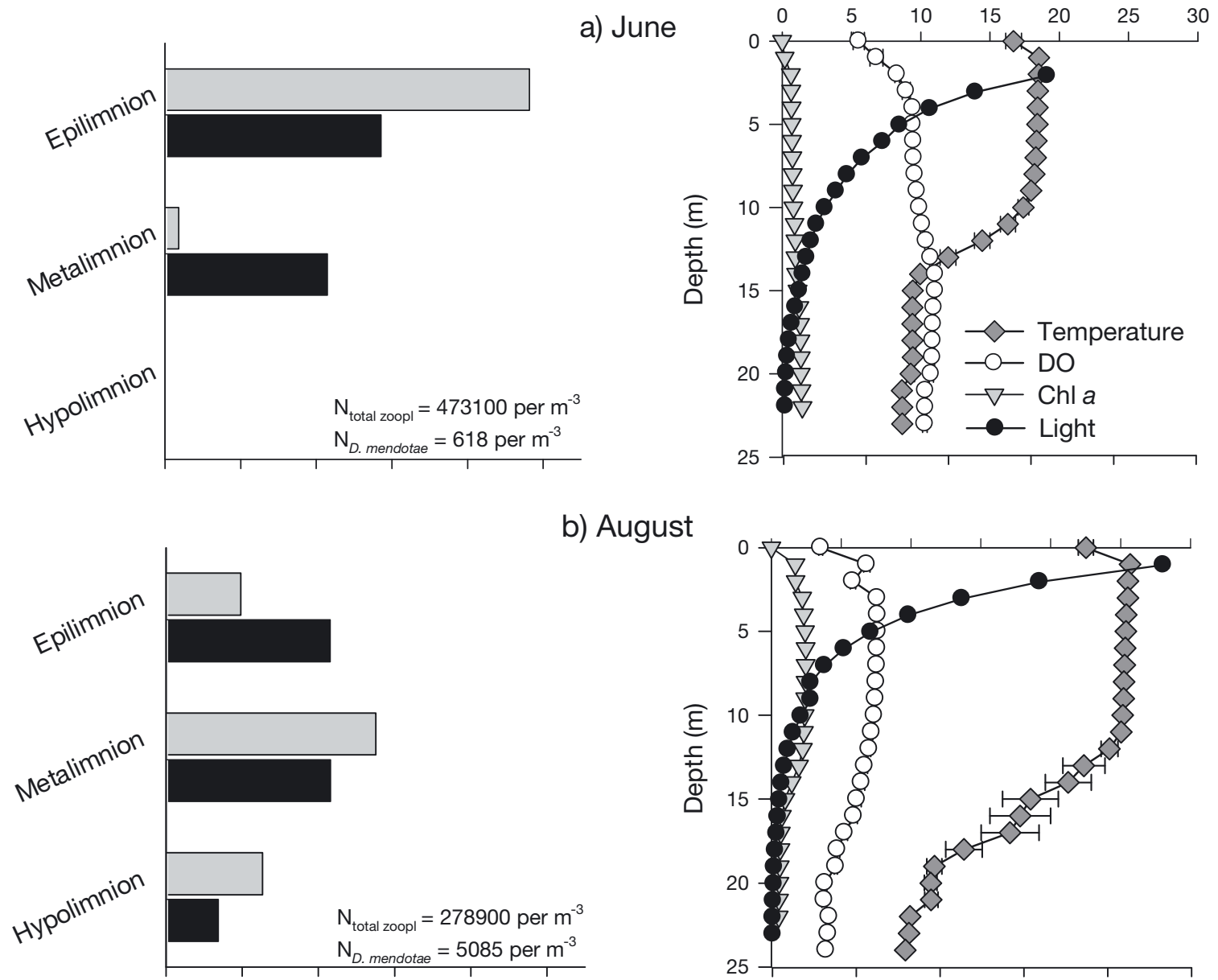

b) August

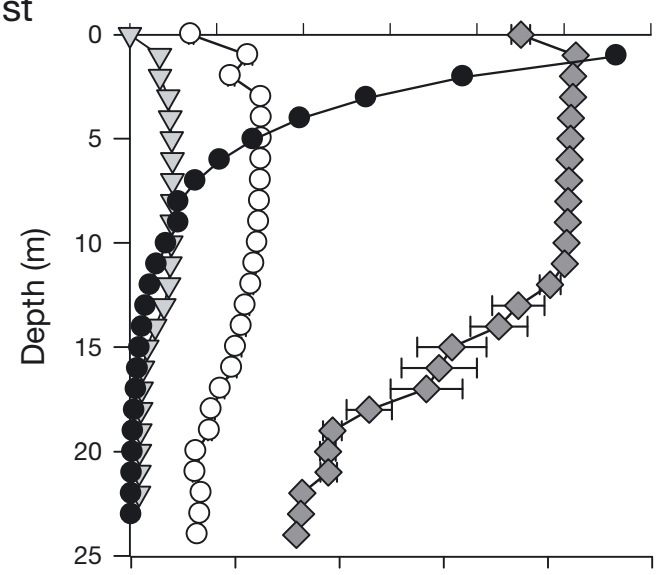

c) September

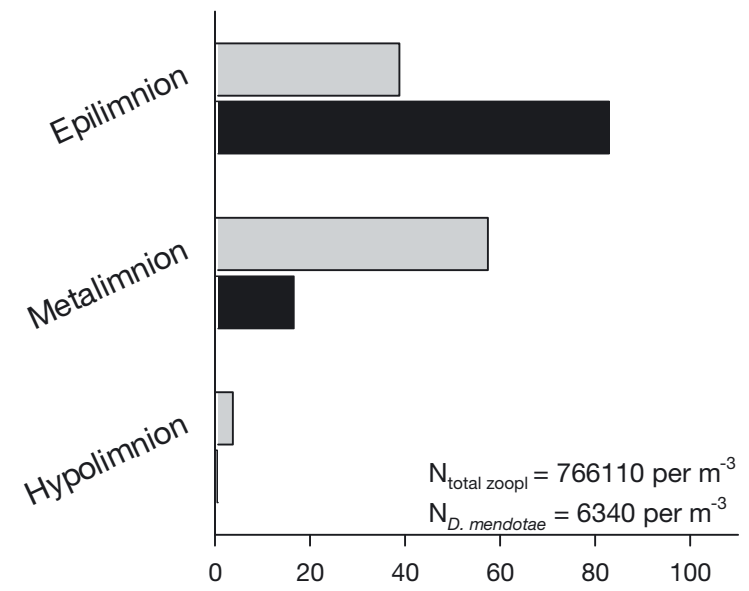

Relative zooplankton vertical distribution (\%)

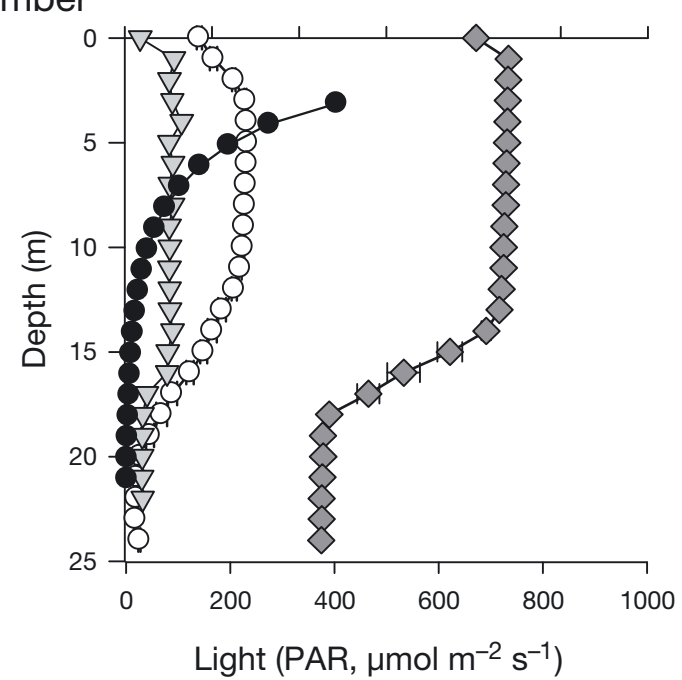

Fig. 2. Temperature $\left({ }^{\circ} \mathrm{C}\right)$, dissolved oxygen $\left(\mathrm{mg} \mathrm{O}_{2} \mathrm{l}^{-1}\right)$, chlorophyll a $\left(\mu \mathrm{g} \mathrm{l}^{-1}\right)$, light (photosynthetically active radiation-PAR, $\mu \mathrm{mol} \mathrm{m} \mathrm{m}^{-2} \mathrm{~s}^{-1}$ ), and distribution (gray bar = day; black bar = night) of Daphnia mendotae at Site B in central Lake Erie during (a) June, (b) August, and (c) September 2005. Depths represented by the epilimnion, metalimnion, and hypolimnion, respectively,

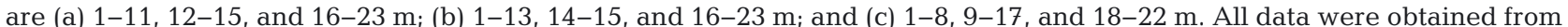
the International Field Years on Lake Erie (IFYLE) database (www.glerl.noaa.gov/ifyle/). If not visible, error bars (SE; shown only for temperatuer and DO) in right-hand panels are smaller than the symbol size 


\section{MATERIALS AND METHODS}

\section{Laboratory experiment 1: temperature and DO effects on survivorship}

To test the independent and interactive effects of temperature and DO concentration on survival of Daphnia mendotae, we conducted a 6 h survivorship experiment using 2 temperature treatments (10 and $\left.25^{\circ} \mathrm{C}\right)$ and $4 \mathrm{DO}$ concentration treatments $(1,2,4$, and $8 \mathrm{mg} \mathrm{O} \mathrm{O}^{-1}$; i.e. 8 total treatments). While DO concentration in the epilimnion of Lake Erie rarely drops below $4 \mathrm{mg} \mathrm{O}_{2} \mathrm{l}^{-1}$, and temperature in Lake Erie's hypolimnion never reaches $25^{\circ} \mathrm{C}$, we included these ecological threshold treatments to allow for a full experimental design. Moreover, relatively warm temperatures coupled with low DO are common in many aquatic systems (e.g. wetlands, reservoirs, estuaries), and our experiments may be informative of responses in these types of systems.

We used Daphnia mendotae neonates that we reared at $\sim 20^{\circ} \mathrm{C}$ from a single clone originally collected from Lake Erie. Doing so for this and the subsequent experiment allowed us to remove individual size and age as confounding effects. Further, small individuals (<1.0 mm), including Daphnia neonates, have been shown to exhibit DVM in response to varying habitat conditions (Kessler \& Lampert 2004), although the degree of DVM exhibited by neonates can be less than adults in some systems (Kessler 2004).

Daphnia mendotae used in our experiments were fed freeze-dried green algae (Chlorella sp.) (Wilson \& Hay 2007). Experimental water was collected from oligotrophic Gull Lake, Michigan, USA, filtered, and autoclaved prior to use. The experimental water was transferred to capped Pyrex bottles $(125 \mathrm{ml} ; \mathrm{n}=5$ per treatment, i.e. $\mathrm{N}=40)$. High $\left(8 \mathrm{mg} \mathrm{O}_{2} \mathrm{l}^{-1}\right)$ and low $\left(1,2\right.$, and $\left.4 \mathrm{mg} \mathrm{O}_{2} \mathrm{l}^{-1}\right)$ DO concentrations were then prepared by bubbling ambient air and nitrogen, respectively.

We began the experiments by adding 2 Daphnia mendotae neonates ( $<24 \mathrm{~h}$ old) to each bottle without food. While Daphnia can tolerate lower DO concentrations when acclimated over time (Zeis et al. 2004), the experimental animals were not acclimated (temperature or DO) prior to the experiments, because our objective was to evaluate DO tolerance of $D$. mendotae in response to abrupt shifts in temperature and DO concentration that they experience during their DVM. Bottles were immediately sealed to minimize changes in DO concentration and placed in incubators to maintain constant temperatures (10 or $25^{\circ} \mathrm{C}$ ) with an $11 \mathrm{~h}$ light:13 $\mathrm{h}$ dark photoperiod. At regular intervals $(1,2,4$, and $6 \mathrm{~h}$ after start of the experiments), D. mendotae survivorship was recorded. DO concentration was measured at the end of the experiment.

\section{Laboratory experiment 2: temperature and food quantity effects on growth and condition}

To test the independent and interactive effects of temperature and food quantity on the growth and condition of Daphnia mendotae, we conducted a $30 \mathrm{~h}$ experiment with 3 food quantity treatments (starvation: $0 \mathrm{mg}$ dry wt $\mathrm{l}^{-1}$; low ration: $0.25 \pm 0.02 \mathrm{mg}$ dry wt $\mathrm{l}^{-1}$; and high ration: $1.2 \pm 0.05 \mathrm{mg}$ dry wt $\mathrm{l}^{-1}$ ) and 2 temperature treatments $\left(10\right.$ and $25^{\circ} \mathrm{C}$ ) (i.e. 6 total treatments). We used the same D. mendotae clone for this experiment as was used in the survivorship experiment. At the start of the experiment, we measured the body length (from the anterior margin of the head to the base of the tail spine; $\pm 0.001 \mathrm{~mm}$ ) of 15 random individual neonates under a dissecting microscope, using their mean length as the initial length for all treatments. Samples were then preserved in RNA Later ${ }^{\mathrm{TM}}$ (Ambion) for subsequent measurements of RNA content (Gorokhova \& Kyle 2002). We began the experiments by adding 1 neonate to a $100 \mathrm{ml}$ Pyrex bottle ( $\mathrm{n}=6$ per treatment, i.e. $\mathrm{N}=36$ ) filled with autoclaved Lake Erie experimental water without (starvation) or with freeze-dried Chlorella sp. Freeze-dried algae was preferred over live algae to minimize potential confounding factors related to algal growth. Bottles were then placed in incubators (10 or $25^{\circ} \mathrm{C}$ ) with an $11 \mathrm{~h}$ light:13 h dark photoperiod. During the day, the bottles were turned every $4 \mathrm{~h}$ to resuspend food (dead cells of Chlorella, a very small alga, sink at a rate of $\sim 4.2 \mathrm{~mm} \mathrm{~h}^{-1}$ ). After $30 \mathrm{~h}, D$. mendotae were removed from the bottles, and their body lengths measured under a dissecting microscope before storage in RNA Later ${ }^{\mathrm{TM}}$ (Gorokhova \& Kyle 2002, Gorokhova 2005).

\section{Field collections}

Daphnia mendotae were collected from central Lake Erie (Site B; Fig. 1) on 17-18 June, 16-17 August, and 17-18 September of 2005 using a full water column tow (at $0.5 \mathrm{~m} \mathrm{~s}^{-1}$ ) with a $0.5 \mathrm{~m}$ diameter, metered zooplankton net (153 $\mu \mathrm{m}$ mesh). All samples were concentrated using a $64 \mu \mathrm{m}$ sieve and transferred into $1.5 \mathrm{ml}$ tubes filled with RNA Later ${ }^{\mathrm{TM}}$ $\left(<5 \%\right.$ sample vs. RNA Later ${ }^{\mathrm{TM}}$ in a tube) (Gorokhova 
\& Kyle 2002). In the laboratory, D. mendotae were identified, measured $( \pm 0.001 \mathrm{~mm})$, and transferred into individual tubes for subsequent nucleic acid analyses. Prior to use, all glassware and equipment used in processing zooplankton samples were cleaned with RNAse Erase ${ }^{\mathrm{TM}}$ (MP Biomedicals).

\section{RNA content analyses}

RNA content of Daphnia mendotae from laboratory experiments and field collections was determined by total fluorescence following established methods (e.g. Gorokhova \& Kyle 2002, Roberts et al. 2011). Daphnia mendotae samples were removed from RNA Later ${ }^{\mathrm{TM}}$, rinsed with RNAse-free water, and homogenized in extraction buffer (50 $\mu \mathrm{l}, 1 \%$ sarcosyl in TE buffer) (Höök et al. 2008). Samples underwent a repeated sequence $(n=3)$ of an ultrasound bath (30 s) and an ice bath (1 min) (Holmborn et al. 2009), and were shaken for $2 \mathrm{~h}$ at room temperature (Höök et al. 2008). The subsamples $(5 \mu \mathrm{l})$ and TE buffer $(65 \mu \mathrm{l})$ then were transferred to a microplate well. After RiboGreen (Molecular Probes; $70 \mu$ l) was added to each well, fluorescence was measured using a microplate reader $\left(\mathrm{FL}_{\mathrm{x}} 800\right.$, Bio-Tek instruments with KCjunior software) (Roberts et al. 2011). Fluorometric determination was repeated after digestion with diluted (1:99) RNAse (5 $\mu \mathrm{l}$ ) and dark incubation for $30 \mathrm{~min}$ at $37^{\circ} \mathrm{C}$ (Gorokhova \& Kyle 2002, Höök et al. 2008). DNA and RNA contents of samples were determined through comparison with DNA and RNA standards. The overall standard curve slope ratio $\left(m_{\mathrm{DNA}} / m_{\mathrm{RNA}}\right)$ was $2.54 \pm 0.09($ mean $\pm \mathrm{SE})$.

\section{Statistical analyses}

Normality of data and homogeneity of variance were evaluated using Shapiro-Wilks $W$ test and Levene's test, respectively. Prior to analyses, data were $\log _{10}$-transformed as necessary to meet statistical assumptions.

Statistical differences in final survival rate among treatment groups in Expt 1 were tested using 2-way log-linear analysis of frequency (Quinn \& Keough 2002). Statistical differences in growth, relative changes in body length and RNA content, among treatment groups in Expt 2 were tested using 2-way analysis of variance (ANOVA). We performed F-tests to test significance of differences (planned post hoc comparisons) between specific treatment groups (Ruxton \& Beauchamp 2008).
We evaluated statistical significance of the relationship between body length and RNA content of field-collected Daphnia mendotae using linear regression. Preliminary analysis of differences in RNA content of $D$. mendotae among months, using analysis of covariance (ANCOVA) with body length as a covariate, showed a violation of the homogeneous slopes assumption. Thus, we used the Wilcox modification of the Johnson-Neyman procedure (Quinn \& Keough 2002). We evaluated differences in mean body length among months using 1-way ANOVA, which, if significant, was followed by Tukey's honestly significant difference (HSD) test. All statistical analyses were performed at the significance level of $\mathrm{p}<0.05$ using STATISTICA 7.1 (StatSoft), except for the Wilcox procedure, which was performed with WILCOX v.3.2 (Wilcox 1987).

\section{RESULTS}

\section{Laboratory experiment 1: temperature and DO effects on survivorship}

At $25^{\circ} \mathrm{C}$, the survival rate of Daphnia mendotae exposed to $8 \mathrm{mg} \mathrm{O}_{2} \mathrm{l}^{-1}$ remained $100 \%$, whereas at $10^{\circ} \mathrm{C}$, it slightly dropped after $2 \mathrm{~h}$ but remained at $\sim 90 \%$ until the end of the experiment (Fig. 3). When D. mendotae was exposed to $4 \mathrm{mg} \mathrm{O} \mathrm{I}^{-1}$ at $25^{\circ} \mathrm{C}$, the survivorship began declining after $1 \mathrm{~h}$ and reached only $\sim 60 \%$ survival at the end of the experiment (Fig. 3). However, neonates exposed to $4 \mathrm{mg} \mathrm{O}_{2} \mathrm{l}^{-1}$ at $10^{\circ} \mathrm{C}$ showed high survivorship ( 90\%) even after $6 \mathrm{~h}$ (Fig. 3). When D. mendotae were exposed to 2 and $1 \mathrm{mg} \mathrm{O} \mathrm{O}_{2} \mathrm{l}^{-1}$, survivorship immediately decreased, falling below $50 \%$ for 3 of these 4 treatments (survival remained higher, $\sim 70 \%$, in the $2 \mathrm{mg} \mathrm{O}_{2} \mathrm{l}^{-1}$ at $25^{\circ} \mathrm{C}$ treatment; Fig. 3). While log-linear analyses showed no difference between temperature treatments (partial likelihood ratio $\chi^{2}=0.06$, $\mathrm{df}=1, \mathrm{p}=$ $0.80)$, DO treatments significantly affected survival $\left(\chi^{2}=53.8, \mathrm{df}=3, \mathrm{p}<0.001\right)$. A significant DOtemperature interaction also was observed $\left(\chi^{2}=8.88\right.$, $\mathrm{df}=3, \mathrm{p}<0.05)$; in particular, survivorship of neonates exposed to the treatment with $2 \mathrm{mg} \mathrm{O}_{2} \mathrm{l}^{-1}$ at $25^{\circ} \mathrm{C}$ was substantially higher $(\sim 70 \%)$ than at $10^{\circ} \mathrm{C}$ $(\sim 35 \%)$ at the end of experiment (Fig. 3).

\section{Laboratory experiment 2: temperature and food quantity effects on growth and condition}

No difference in growth was observed among the temperature $\left(F_{1,30}=0.39, \mathrm{p}=0.54\right)$ or food quantity 


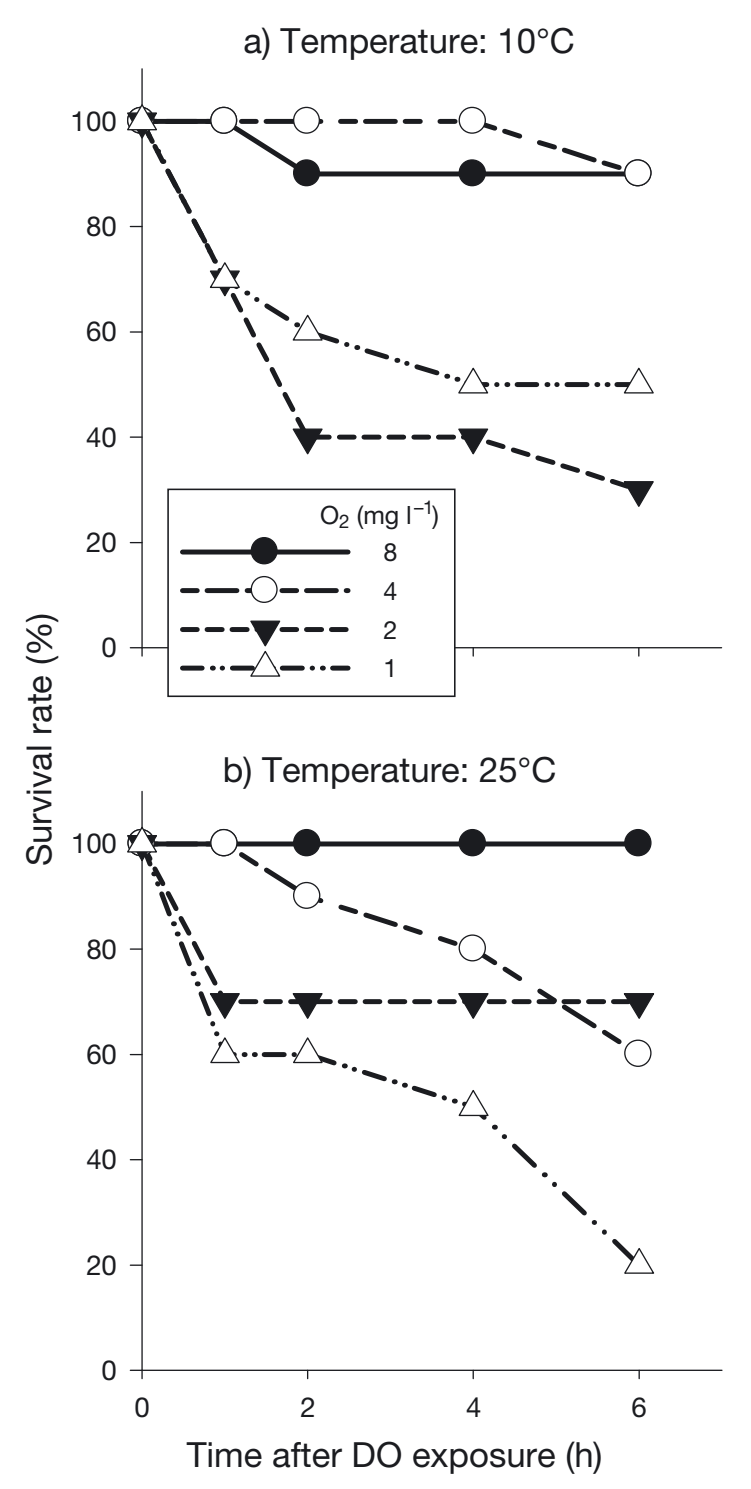

Fig. 3. Daphnia mendotae. Survivorship of neonates when exposed to $1,2,4$, and $8 \mathrm{mg} \mathrm{O}_{2} \mathrm{l}^{-1}$ at each time interval at (a) $10^{\circ} \mathrm{C}$ and (b) $25^{\circ} \mathrm{C}$ in the laboratory

$\left(F_{2,30}=0.04, \mathrm{p}=0.96\right)$ treatments, nor was an interaction observed $\left(F_{2,30}=0.24, \mathrm{p}=0.78\right)$; body length of Daphnia mendotae, averaged across all treatments, increased by $\sim 20 \%$ over 30 h (Fig. 4a). By contrast, RNA content (our proxy for condition) responded to the experimental treatments. Whereas temperature did not affect RNA content $\left(F_{1,30}=1.70, \mathrm{p}=0.20\right)$, food quantity did $\left(F_{2,30}=3.98, \mathrm{p}<0.05\right)$, with no interaction between food quantity and temperature being detected $\left(F_{2,30}=0.31, \mathrm{p}=0.97\right.$; Fig. $\left.4 \mathrm{~b}\right)$. Despite the lack of a significant temperature effect, the RNA content of individuals exposed to $10^{\circ} \mathrm{C}$ was consistently lower than those exposed to $25^{\circ} \mathrm{C}$, regardless of food availability. Further, at $10^{\circ} \mathrm{C}$, RNA content of D. men-
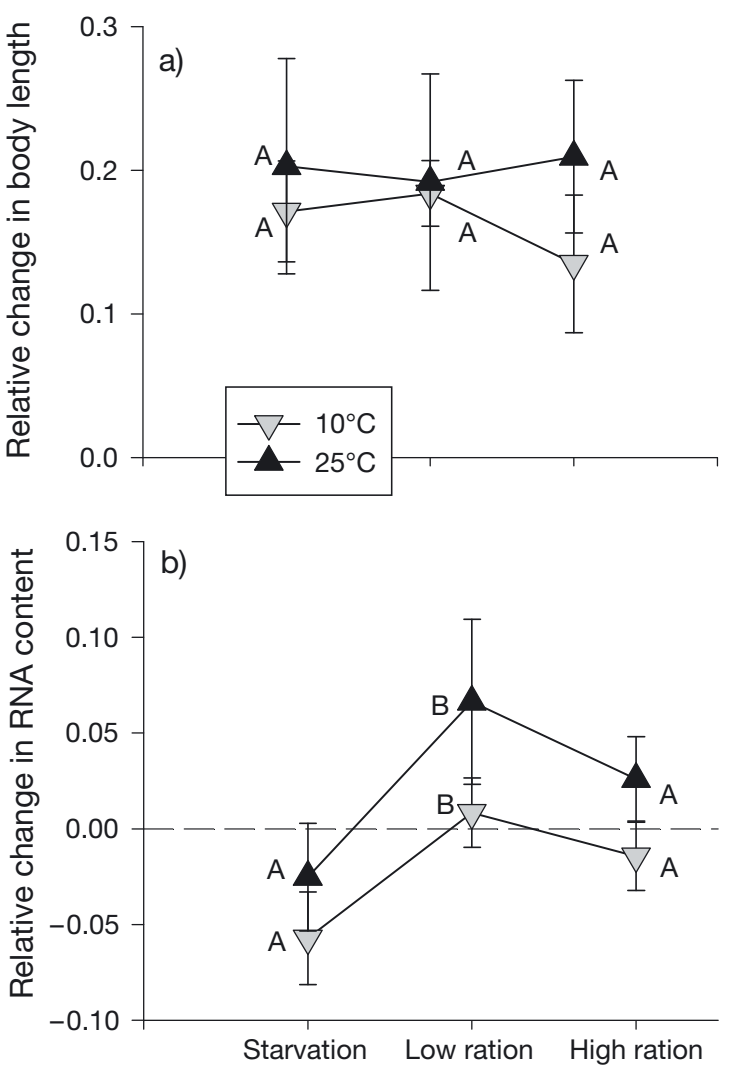

Fig. 4. Daphnia mendotae. Relative mean changes in (a) body length $(\mathrm{mm})$ and (b) RNA content $\left(\mu \mathrm{g}\right.$ ind $\left.^{-1}\right)$ of neonates exposed to 3 food levels (starvation; low ration: $0.25 \pm 0.02 \mathrm{mg}$ dry $\mathrm{wt} \mathrm{l}^{-1}$; and high ration: $1.2 \pm 0.05 \mathrm{mg}$ dry wt $\mathrm{l}^{-1}$ ) and 2 water temperatures $\left(10\right.$ and $\left.25^{\circ} \mathrm{C}\right)$ in the laboratory. Error bars indicate \pm 1 SE. Different letters indicate a significant difference among the experimental treatments by F-test (note no significant difference between the temperature treatments for all the food treatments)

dotae in the starvation treatment decreased from initial content, whereas no changes from initial RNA content were evident in the low- and high-ration treatments (Fig. 4b). At $10^{\circ} \mathrm{C}$, RNA content in the starvation treatment was significantly lower than in the low ration treatment groups $\left(F_{1,30}=7.61, \mathrm{p}<0.05\right.$; Fig. 4b). Additionally, no relationship was found between relative changes in body length and RNA content ( $F_{1,4}=0.76, \mathrm{p}=0.45$; Fig. 5).

\section{Field observations}

Body length of field-collected Daphnia mendotae ranged from 0.7 to $1.9 \mathrm{~mm}$ during June, 0.6 to $1.7 \mathrm{~mm}$ during August, and 0.5 to $1.2 \mathrm{~mm}$ during September (Fig. 6a-c). Mean body length of D. mendotae collected during September $(0.9 \pm 0.1 \mathrm{~mm})$ was significantly lower than those collected during June (1.2 \pm 


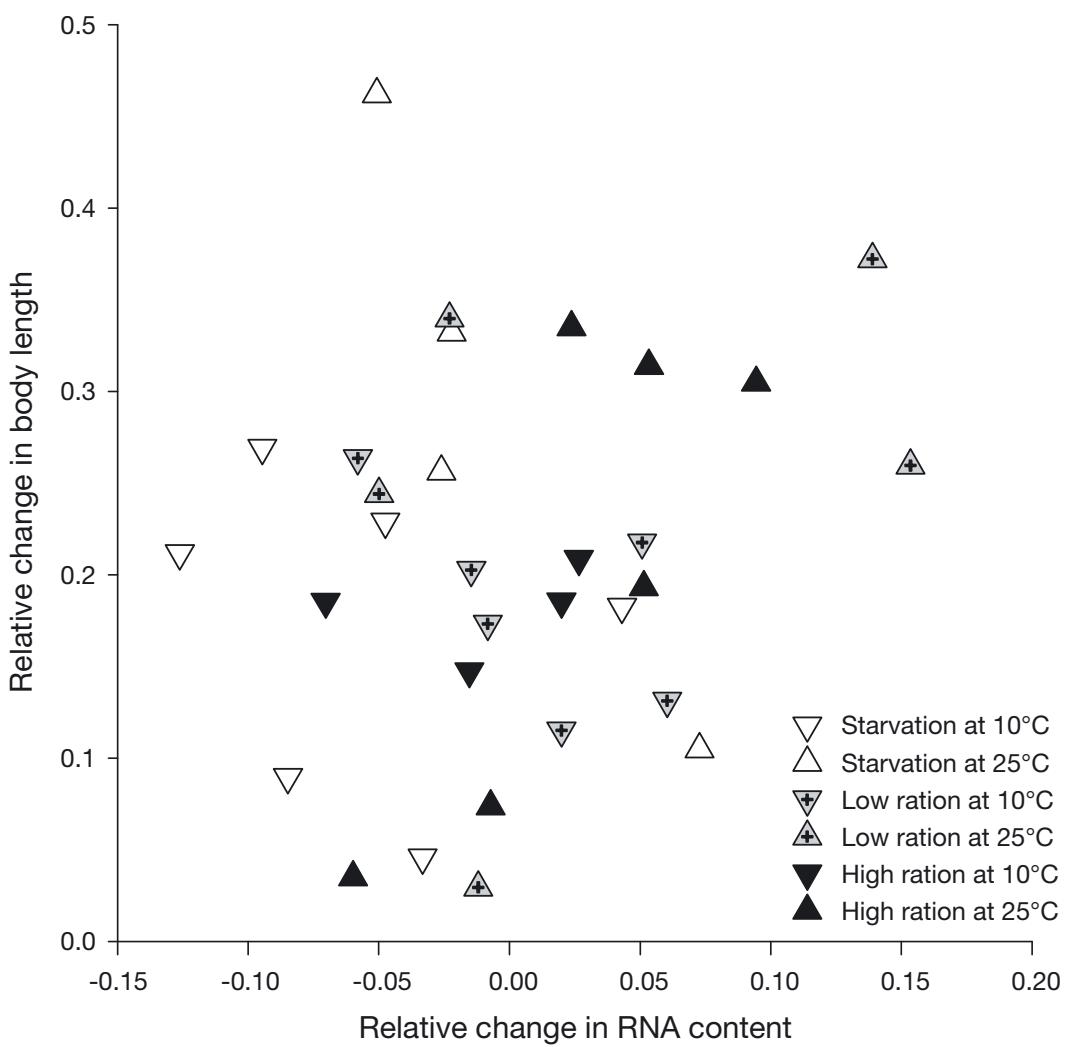

Fig. 5. Daphnia mendotae. Relationship between relative changes in individual neonate body length and RNA content from growth experiments

$0.1 \mathrm{~mm})$ or August $(1.1 \pm 0.1 \mathrm{~mm})\left(F_{2,72}=5.9, \mathrm{p}<0.05\right.$; Fig. $6 \mathrm{a}-\mathrm{c}$ ). RNA content of $D$. mendotae was positively related to body length during all sampling months (Fig. 6a-c). Body length-specific RNA content during June was higher than during August (Wilcox procedure, $\mathrm{T} 3_{47}=3.50, \mathrm{p}<0.05$; Fig. 6a,b). However, body length-specific RNA content during September did not differ from that of August (Wilcox procedure, $\mathrm{T} 3_{30}=3.52, \mathrm{p}>0.05$; Fig. 6b,c).

\section{DISCUSSION}

Our short-term survivorship experiments demonstrated great sensitivity of Daphnia mendotae to DO availability. When exposed to hypoxia (1 or $2 \mathrm{mg} \mathrm{O}$ $\mathrm{l}^{-1}$ ), survival declined rapidly, with $50 \%$ of the individuals dying in these treatments within $4 \mathrm{~h}$ (with the exception of individuals exposed to $2 \mathrm{mg} \mathrm{O}_{2} \mathrm{l}^{-1}$ at $25^{\circ} \mathrm{C}$, which was likely due to some of the replicates exhibiting slightly higher DO concentrations than planned). This rapid decline in survivorship suggests that $D$. mendotae have a considerably lower tolerance of hypoxia than other daphnid species such as D. magna (Nebeker et al. 1992) and D. pulicaria
(Larsson \& Lampert 2011). These interspecific differences also support findings from field observations. For example, Vanderploeg et al. (2009a) found that $D$. longiremis migrated into the hypolimnion even during severe hypoxia $\left(\leq 1.0 \mathrm{mg} \mathrm{O}_{2}\right.$ $\mathrm{l}^{-1}$ ) in central Lake Erie, whereas D. mendotae did not, almost disappearing from the hypoxic hypolimnion during summer. Tolerance of hypoxia also can be temperature-dependent; because oxygen consumption decreases with decreasing temperature, aquatic organisms tend to be more tolerant to low DO concentration at low temperature than at high temperature (Vargo \& Sastry 1977, Johnson \& McMahon 1998). Data from our survivorship experiment, however, did not indicate that substantial drop in temperature in the hypolimnion would influence DO tolerance of $D$. mendotae.

Vanderploeg et al. (2009a) suggested that sensitivity to hypoxia was responsible for differences in vertical distribution among zooplankton species including Daphnia mendotae in central Lake Erie during summer. In that study, a substantially lower proportion $(<1 \%)$ of the $D$. mendotae population was found in the hypoxic hypolimnion during late summer (September) relative to the pre-hypoxia period (Vanderpleog et al. 2009a). However, information on the sensitivity of $D$. mendotae to DO availability was previously unknown to Vanderploeg et al. (2009a), thus limiting their ability to discern whether distributional differences among months was due to behavioral avoidance of low DO conditions or hypoxia-induced mortality. Given our findings herein, we now know that $D$. mendotae is extremely sensitive to changes in DO availability, as shown with some other Daphnia sp. (Lass et al. 2000). Further, because the total population size of D. mendotae remained high in central Lake Erie in September (August: 5085 ind. $\mathrm{m}^{-3}$ vs. September: 6450 ind. $\mathrm{m}^{-3}$, Vanderploeg et al. 2009a; see Fig. 2 herein), we agree with Vanderploeg et al. (2009a) that hypoxia avoidance (rather than hypoxia-induced mortality in the hypolimnion) plays a large role in driving vertical distribution patterns of $D$. mendotae.

This hypoxia-induced vertical habitat compression likely causes zooplankton to experience short-term changes in habitat conditions that can influence growth and future fitness. Daphnia mendotae from Lake Michigan, for example, expressed higher growth 

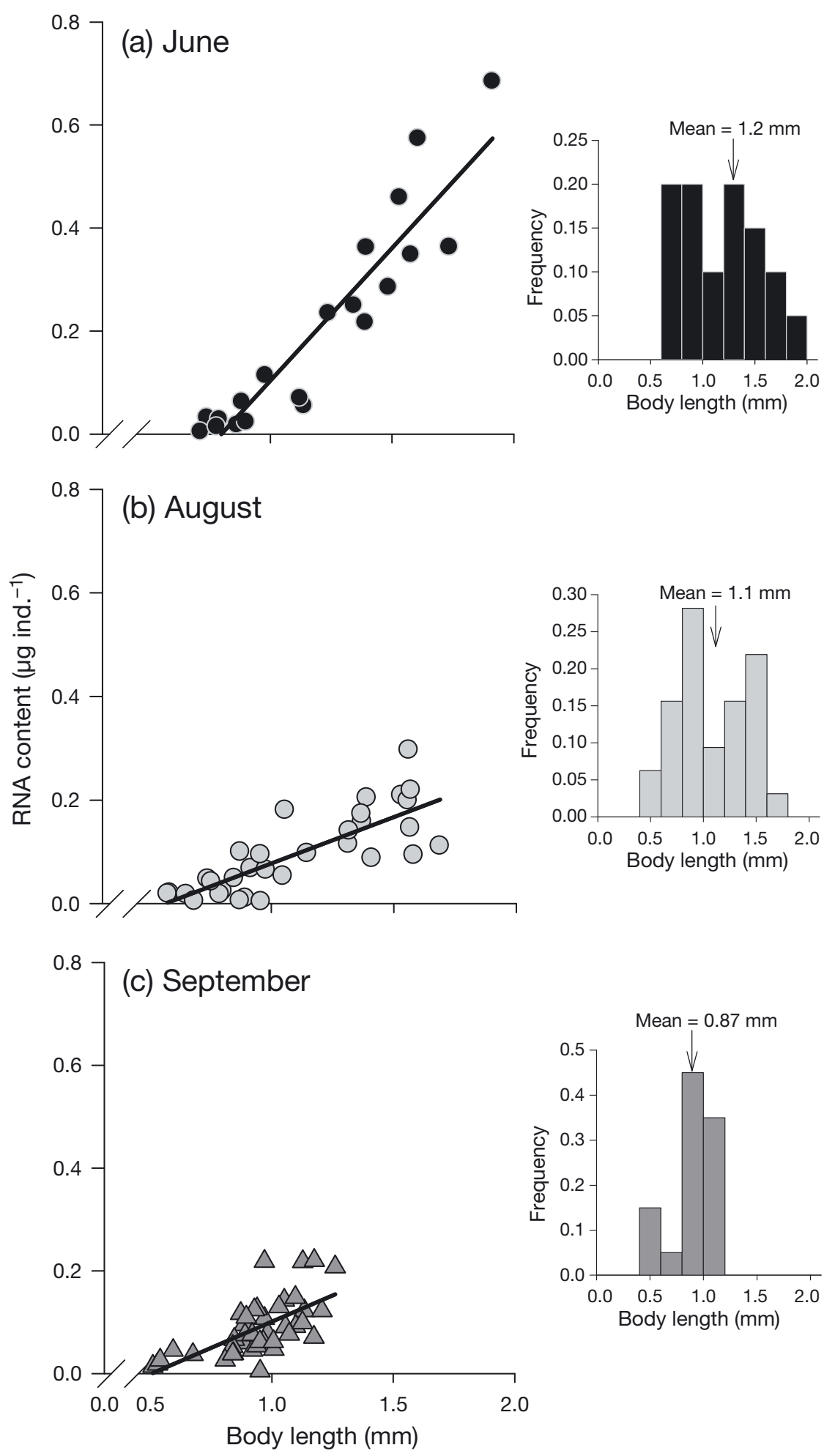

Fig. 6. Daphnia mendotae. Relationship between relative changes in body length $(\mathrm{mm})$ and RNA content ( $\mu \mathrm{g}$ ind.$^{-1}$; left column) and size distribution of individuals at Site B in central Lake Erie (right column) during (a) June [RNA = 0.52(body length) -0.41 , adj. $\mathrm{R}^{2}=0.85, \mathrm{n}=20, \mathrm{p}<0.001$ ], (b) August [RNA = 0.18 (body length) -0.10 , adj. $\mathrm{R}^{2}=0.63, \mathrm{n}=32, \mathrm{p}<0.001$ ], and (c) September $\left[\right.$ RNA $=0.15$ (body length) -0.07, adj. $\left.\mathrm{R}^{2}=0.24, \mathrm{n}=20, \mathrm{p}<0.001\right]$. Solid lines indicate the best-fit, least squares regression line

rates at epilimnetic temperatures $\left(21^{\circ} \mathrm{C}\right)$ than at hypolimnetic temperatures $\left(8^{\circ} \mathrm{C}\right)$ after $5 \mathrm{~d}$ (Pangle \& Peacor 2010). By contrast, our experimental data showed that relatively large differences in water temperature (10 vs. $25^{\circ} \mathrm{C}$ ) and food density did not affect $D$. mendotae growth in length over $30 \mathrm{~h}$. While this lack of response in body growth to temperature or food availability may reflect a relatively short experimental period, nutrients from maternal investments likely contributed to energetic needs for $D$. mendotae neonates (Kessler 2004) and thereby blurred potential responses to food or temperature.

Unlike body growth, RNA content in Daphnia mendotae responded to changes in food quantity in our experiment; the RNA content of starved D. mendotae did not increase during $30 \mathrm{~h}$, indicating an immediate response to short-term starvation in RNA production. Because RNA production is a precursor to protein synthesis (i.e. growth; Elser et al. 2000), it is an ecologically relevant indicator for short-term condition and growth potential (e.g. McKee \& Ebert 1996, Gorokhova \& Kyle 2002). In fact, since RNA production also has been shown to decline under suboptimal habitat conditions, such as low food availability (Zhou et al. 2001, Norkko et al. 2005), RNA content may be a more sensitive indicator of both positive and negative habitat conditions than coarser measures of change in size.

Although the temperature treatment effect on RNA content in our growth experiment was not statistically significant, RNA content in Daphnia mendotae exposed to epilimnetic temperature $\left(25^{\circ} \mathrm{C}\right)$ appeared to be consistently higher than in those exposed to temperature more representative of Lake Erie's hypolimnion $\left(10^{\circ} \mathrm{C}\right)$. Weak temperature effects on RNA production also have been observed in other zooplankton species such as the cope- 
pods Calanus finmarchicus (Wagner et al. 2001) and Acartia bifilosa (Gorokhova 2003). Moreover, lack of an increase in RNA content in $D$. mendotae at $10^{\circ} \mathrm{C}$ suggests that our study individuals may have experienced some temperature-induced costs, including reduced feeding and digestion rates, regardless of food availability. Thus, the lack of significant differences among the experimental treatments may not necessarily indicate the absence of a temperature effect on RNA production in D. mendotae.

During the pre-hypoxia period from June to August in central Lake Erie, size-specific RNA content of the Daphnia mendotae population dropped considerably. This change in RNA content may reflect a shift in vertical distribution of $D$. mendotae that altered ambient conditions experienced by individuals (e.g. temperature; Vanderpleog et al. 2009a), thereby affecting growth potential. Based on August habitat quality (e.g. high temperature and algal abundance), growth of $D$. mendotae is likely to benefit from remaining in the epilimnion and metalimnion (Guisande et al. 1991, Loose \& Dawidowicz 1994). However, $\sim 22 \%$ of the $D$. mendotae population appeared to migrate downward and remain in the hypolimnion during August (Vanderpleog et al. 2009a). These migrating individuals may thus have experienced suboptimal habitat conditions for growth (e.g. less food and lower temperature) in August, which may have depressed energetic gain (e.g. feeding and digestion rates) and subsequently RNA production, as observed in our laboratory experiments.

During the peak-hypoxia period in September, central Lake Erie Daphnia mendotae remained in the upper water column, likely in response to the hypolimnetic hypoxia development. Surprisingly, despite habitat conditions in the upper water column that should favor RNA production and growth (as observed in our laboratory experiment), size-specific RNA content of $D$. mendotae in September changed little from August (i.e. it remained low). Furthermore, samples of $D$. mendotae collected from central Lake Erie during September also consisted of only small individuals $(<\sim 1.25 \mathrm{~mm}, \sim 24 \%$ reduction in average size), which contrasts the larger range of sizes collected during June and August. While seasonal (intrinsic) population dynamics may have influenced growth potential to some extent (Tessier et al. 1992), low RNA content and small body size in September may have resulted from alternative extrinsic mechanisms in the upper water column of central Lake Erie; in particular, food quality (e.g. Müller-Navarra \& Lampert 1996) and risk of size-dependent predation (e.g. Tessier et al. 1992).
Although higher chlorophyll a concentrations were found in the metalimnion and epilimnion of central Lake Erie during September than during June (Vanderpleog et al. 2009a), food quality (i.e. phytoplankton community composition) may not have been equally high in the upper water column in September due to the presence of blue-green algae, possibly negatively affecting Daphnia mendotae RNA production (Vrede et al. 2002) and growth (Pangle \& Peacor 2010). Densities of toxic cyanobacteria such as Microcystis aeruginosa, which are a relatively poor food resource and can be harmful to cladoceran zooplankton (Wilson et al. 2006), have been increasing in recent years (post-2003) during late summer and fall in Lake Erie (OEPA 2010).

Enhanced size-dependent predation by planktivores may also may occurred during the peakhypoxia period in central Lake Erie. Densities of epilimnetic and metalimnetic planktivores, such as emerald shiners Notropis atherinoides, Leptodora kindti and Bythotrephes longimanus, remained high in September (Pothoven et al. 2009; Vanderploeg et al. 2009a), while demersal, invertivorous fishes such as yellow perch Perca flavescens and rainbow smelt Osmerus mordax moved upward to avoid the hypoxic hypolimnion during this time (Pothoven et al. 2009, Roberts et al. 2009). Collectively, these planktivores congregated around the thermocline and fed primarily on zooplankton instead of benthic macroinvertebrates (Pothoven et al. 2009, Roberts et al. 2009). Furthermore, the body size of Daphnia can be reduced by the presence of predators alone as an adaptive response to size-dependent predation risk (Dodson 1988). Kairomones released from predatory zooplankton $B$. longimanus also have been shown to reduce growth of Great Lakes $D$. mendotae (Pangle \& Peacor 2006).

\section{CONCLUSIONS}

Changes in growth have ecological and evolutionary implications for life-history strategies (e.g. clutch size) in zooplankton (Orcutt \& Porter 1984, Hanazato \& Dodson 1995, Weetman \& Atkinson 2002). Data from our laboratory and field studies demonstrate that the cladoceran $D$. mendotae is highly sensitive to hypoxia, which appears to influence its vertical migration behavior in central Lake Erie. During the peak-hypoxia period, the majority of Daphnia mendotae (and many other zooplankton taxa; Vanderpleog et al. 2009a) remained in the upper water column to avoid the hypoxic hypolimnion, congregating 
around the thermocline along with other organisms such as planktivorous fishes (Roberts et al. 2009, Vanderploeg et al. 2009b). In turn, this compression of organisms into a small portion of the water column likely exposed hypoxia-intolerant $D$. mendotae to suboptimal habitat conditions (e.g. low quality food and enhanced predation risk), which may have contributed to reduction in average body length and RNA content observed herein. Because hypoxia commonly occurs in thermally-stratified aquatic ecosystems, including lakes, reservoirs, and coastal marine ecosystems (Smith 2003), and is expected to become more pervasive with climate change (Justić et al. 1996, Kling et al. 2003, Ficke et al. 2007), we encourage more research in this arena. Because each aquatic species can detect and respond to hypoxia differently, which in turn can drive shifts in vertical distributions and species overlap, we especially encourage investigations that focus on the indirect (sublethal) effects of hypoxia. Only through such investigations will we truly understand the ecological impacts of hypoxia in aquatic ecosystems.

Acknowledgements. We thank all those who provided lab, field, or data management support, including K. Bailey, S. Bickel, A. Clites, S. Constant, S. Lozano, G. Maria, K. Pangle, S. Peacor, S. Sisler, and the crews of both the RV 'Laurentian' and RV 'Lake Guardian'. This work was supported by the NOAA Center for Sponsored Coastal Ocean Research grant (no. NA07OAR432000) with samples and experiments conducted as part of the International Field Years on Lake Erie (IFYLE) program, supported primarily by NOAA-GLERL, the US EPA Great Lakes National Program Office, and the National Sea Grant College Program. This manuscript is an NOAA-GLERL contribution and EcoFore Lake Erie publication no. 12-010.

\section{LITERATURE CITED}

Cole PC, Luecke C, Wurtsbaugh WA, Burkart G (2002) Growth and survival of Daphnia in epilimnetic and metalimnetic water from oligotrophic lakes: the effects of food and temperature. Freshw Biol 47:2113-2122

> Dodson SI (1988) Cyclomorphosis in Daphnia galeata mendotae Birge and $D$. retrocurva Forbes as a predatorinduced response. Freshw Biol 19:109-114

Elser J, Sterner R, Gorokhova E, Fagan W and others (2000) Biological stoichiometry from genes to ecosystems. Ecol Lett 3:540-550

> Ficke AD, Myrick CA, Hansen LJ (2007) Potential impact of global climate change on freshwater fisheries. Rev Fish Biol Fish 17:581-613

Gorokhova E (2003) Relationships between nucleic acid levels and egg production rates in Acartia bifilosa: implications for growth assessment of copepods in situ. Mar Ecol Prog Ser 262:163-172

Gorokhova E (2005) Effects of preservation and storage of microcrustaceans in RNAlater on RNA and DNA degra- dation. Limnol Oceanogr Methods 3:143-148

Gorokhova E, Kyle M (2002) Analysis of nucleic acids in Daphnia: development of methods and ontogenetic variations in RNA-DNA content. J Plankton Res 24:511-522

$>$ Guisande C, Duncan A, Lampert W (1991) Trade-offs in Daphnia vertical migration strategies. Oecologia 87: 357-359

Hanazato T, Dodson SI (1995) Synergistic effects of low oxygen concentration, predator kairomone, and a pesticide on the cladoceran Daphnia pulex. Limnol Oceanogr 40:700-709

> Hanazato T, Yasuno M, Hosomi M (1989) Significance of a low oxygen layer for a Daphnia population in Lake Yunoko, Japan. Hydrobiologia 185:19-27

> Havel JE, Lampert W (2006) Habitat partitioning of native and exotic Daphnia in gradients of temperature and food: mesocosm experiments. Freshw Biol 51:487-498

> Holmborn T, Dahlgren K, Holeton C, Hogfors H, Gorokhova E (2009) Biochemical proxies for growth and metabolism in Acartia bifilosa (Copepoda, Calanoida). Limnol Oceanogr Methods 7:785-794

> Höök TO, Gorokhova E, Hansson S (2008) RNA:DNA ratios of Baltic Sea herring larvae and copepods in embayment and open sea habitats. Estuar Coast Shelf Sci 76:29-35

> Johnson PD, McMahon RF (1998) Effects of temperature and chronic hypoxia on survivorship of the zebra mussel (Dreissena polymorpha) and Asian clam (Corbicula fluminea). Can J Fish Aquat Sci 55:1564-1572

Justić D, Rabalais NN, Turner RE (1996) Effects of climate change on hypoxia in coastal waters: a doubled CO2 scenario for the northern Gulf of Mexico. Limnol Oceanogr 41:992-1003

> Kessler K (2004) Distribution of Daphnia in a trade-off between food and temperature: individual habitat choice and time allocation. Freshw Biol 49:1220-1229

Kessler K, Lampert W (2004) Depth distribution of Daphnia in response to a deep-water algal maximum: the effect of body size and temperature gradient. Freshw Biol 49: 392-401

Kling GW, Hayhoe K, Johnson LB, Magnuson JJ and others (2003) Confronting climate change in the Great Lakes Region: impacts on our communities and ecosystems. Union of Concerned Scientists, Cambridge, MA, and Ecological Society of America, Washington, DC

$>$ Lampert W (1989) The adaptive significance of diel vertical migration of zooplankton. Funct Ecol 3:21-27

Lampert W (2011) Daphnia: development of a model organism in ecology and evolution. In: Kinne O (ed) Excellence in ecology. Book 21. International Ecology Institute, Oldendorf/Luhe

Lampert W, McCauley E, Manly BFJ (2003) Trade-offs in the vertical distribution of zooplankton: ideal free distribution with costs? Proc R Soc B270:765-773

Larsson P, Lampert W (2011) Experimental evidence of a low-oxygen refuge for large zooplankton. Limnol Oceanogr 56:1682-1688

Lass S, Boersma M, Spaak P (2000) How do migrating daphnids cope with fish predation risk in the epilimnion under anoxic conditions in the hypolimnion? J Plankton Res 22:1411-1418

Loose CJ, Dawidowicz P (1994) Trade-offs in diel vertical migration by zooplankton: the costs of predator avoidance. Ecology 75:2255-2263

McKee D, Ebert D (1996) The interactive effects of temperature, food level and maternal phenotype on offspring size 
in Daphnia magna. Oecologia 107:189-196

Müller-Navarra D, Lampert W (1996) Seasonal patterns of food limitation in Daphnia galeata: separating food quantity and food quality effects. J Plankton Res 18: 1137-1157

Nebeker AV, Onjukka ST, Stevens DG, Chapman GA, Dominguez SE (1992) Effects of low dissolved oxygen on survival, growth and reproduction of Daphnia, Hyalella and Gammarus. Environ Toxicol Chem 11:373-379

Norkko J, Pilditch CA, Thrush SF, Wells RMG (2005) Effects of food availability and hypoxia on bivalves: the value of using multiple parameters to measure bivalve condition in environmental studies. Mar Ecol Prog Ser 298:205-218

OEPA (2010) Ohio Lake Erie Phosphorus Task Force Final Report. Ohio Environmental Protection Agency (OEPA), Division of Surface Water, Columbus, OH. Available at www.epa.ohio.gov/dsw/lakeerie/ptaskforce/index.aspx

> Orcutt JD, Porter KG (1984) The synergistic effects of temperature and food concentration on life history parameters of Daphnia. Oecologia 63:300-306

Pangle KL, Peacor SD (2006) Non-lethal effect of the invasive predator Bythotrephes longimanus on Daphnia mendotae. Freshw Biol 51:1070-1078

Pangle KL, Peacor SD (2010) Temperature gradients, not food resource gradients, affect growth rate of migrating Daphnia mendotae in Lake Michigan. J Gt Lakes Res 36: 345-350

> Pothoven SA, Vanderploeg HA, Ludsin SA, Höök TO, Brandt SB (2009) Feeding ecology of emerald shiners and rainbow smelt in central Lake Erie. J Gt Lakes Res 35: 190-198

Quinn G, Keough MJ (2002) Experimental designs and data analysis for biologists, 1st edn. Cambridge University Press, Cambridge

Roberts JJ, Höök TO, Ludsin SA, Pothoven SA, Vanderploeg HA, Brandt SB (2009) Effects of hypolimnetic hypoxia on foraging and distributions of Lake Erie yellow perch. J Exp Mar Biol Ecol 381:S132-S142

Roberts JJ, Brandt SB, Fanslow D, Ludsin SA, Pothoven SA, Scavia D, Höök TO (2011) Effects of hypoxia on consumption, growth, and RNA:DNA ratios of young yellow perch. Trans Am Fish Soc 140:1574-1586

Ruxton GD, Beauchamp G (2008) Time for some a priori thinking about post hoc testing. Behav Ecol 19:690-693

Sarnelle O, Wilson AE (2005) Local adaptation of Daphnia pulicaria to toxic cyanobacteria. Limnol Oceanogr 50: $1565-1570$

Smith VH (2003) Eutrophication of freshwater and coastal marine ecosystems a global problem. Environ Sci Pollut Res 10:126-139

Stich HB, Lampert W (1984) Growth and reproduction of migrating and non-migrating Daphnia species under simulated food and temperature conditions of diurnal vertical migration. Oecologia 61:192-196

Taylor JC, Rand PS (2003) Spatial overlap and distribution of anchovies (Anchoa spp.) and copepods in a shallow stratified estuary. Aquat Living Resour 16:191-196

Tessier AJ, Young A, Leibold M (1992) Population dynamics

Editorial responsibility: Jonathan Cole,

Milbrook, New York, USA and body-size selection in Daphnia. Limnol Oceanogr $37: 1-13$

Vanderploeg HA, Ludsin SA, Cavaletto JF, Höök TO and others (2009a) Hypoxic zones as habitat for zooplankton in Lake Erie: Refuges from predation or exclusion zones? J Exp Mar Biol Ecol 381:S108-S120

> Vanderploeg HA, Ludsin SA, Ruberg SA, Höök TO and others (2009b) Hypoxia affects spatial distributions and overlap of pelagic fish, zooplankton, and phytoplankton in Lake Erie. J Exp Mar Biol Ecol 381:S92-S107

Vargo SL, Sastry AN (1977) Acute temperature and low dissolved oxygen tolerances of brachyuran crab (Cancer irroratus) larvae. Mar Biol 40:165-177

Vrede T, Persson J, Aronsen G (2002) The influence of food quality (P:C ratio) on RNA:DNA ratio and somatic growth rate of Daphnia. Limnol Oceanogr 47:487-494

- Wagner MM, Campbell RG, Boudreau CA, Durbin EG (2001) Nucleic acids and growth of Calanus finmarchicus in the laboratory under different food and temperature conditions. Mar Ecol Prog Ser 221:185-197

Weetman D, Atkinson D (2002) Antipredator reaction norms for life history traits in Daphnia pulex: dependence on temperature and food. Oikos 98:299-307

Wilcox RR (1987) New designs in analysis of variance. Annu Rev Psychol 38:29-60

Williamson CE, Sanders RW, Moeller RE, Stutzman PL (1996) Utilization of subsurface food resources for zooplankton reproduction: implications for diel vertical migration theory. Limnol Oceanogr 41:224-233

> Williamson CE, Fischer JM, Bollens SM, Overholt EP, Breckenridgec JK (2011) Toward a more comprehensive theory of zooplankton diel vertical migration: integrating ultraviolet radiation and water transparency into the biotic paradigm. Limnol Oceanogr 56:1603-1623

Wilson AE, Hay ME (2007) A direct test of cyanobacterial chemical defense: variable effects of microcystin-treated food on two Daphnia pulicaria clones. Limnol Oceanogr 52:1467-1479

Wilson AE, Sarnelle O, Tillmanns AR (2006) Effects of cyanobacterial toxicity and morphology on the population growth of freshwater zooplankton: meta-analyses of laboratory experiments. Limnol Oceanogr 51:1915-1924

Winder M, Boersma M, Spaak P (2003) On the cost of vertical migration: Are feeding conditions really worse at greater depths? Freshw Biol 48:383-393

> Wright D, Shapiro J (1990) Refuge availability: a key to understanding the summer disappearance of Daphnia. Freshw Biol 24:43-62

Yerubandi RR, Hawley N, Charlton MN, Schertzer WM (2008) Physical processes and hypoxia in the central basin of Lake Erie. Limnol Oceanogr 53:2007-2020

Zeis B, Maurer J, Pinkhaus O, Bongartz E, Paul RJ (2004) A swimming activity assay shows that the thermal tolerance of Daphnia magna is influenced by temperature acclimation. Can J Zool 82:1605-1613

> Zhou BS, Wu RSS, Randall DJ, Lam PKS (2001) Bioenergetics and RNA/DNA ratios in the common carp (Cyprinus carpio) under hypoxia. J Comp Physiol B 171:49-57

Submitted: September 5, 2011; Accepted: May 7, 2012

Proofs received from author(s): August 11, 2012 